\title{
A CIDADE DE CUNQUEIRO TRES DIRECTORES, TRES DÉCADAS, UN XORNAL
}

Ceferino de Blas

Xornalista

doi:10.17075/mucnoc.2014.063 

Forcadela, M. / T. López / D. Vilavedra (coords.) (2014): Mil e un cunqueiros. Novas olladas para un centenario, Santiago de Compostela, Consello da Cultura Galega. doi:10.17075/mucnoc.2014. pp. 1097-1102

Non se pode entender a figura de Álvaro Cunqueiro sen ambientala en Faro de Vigo — onde escribiu durante trinta nos — e mais na cidade de Vigo, na cal transcorreu un terzo da súa vida adulta. Un deseńo alleo a este triángulo desvirtúa a interlección do personaxe no seu universo vivencial e creativo.

O contexto ao que nos referimos atinxe tres directores: Francisco Leal, Manuel Cerezales e Álvaro Cunqueiro; tres décadas: desde 1950 até 1980; un xornal: FV, vicedecano da prensa española e da cidade que lle empresta o nome.

A cidade de Cunqueiro non é Mondoñedo, solar dos soños. A cidade de Cunqueiro é Vigo, que non figura en ningunha das súas ficcións, pero que é onde vive unha etapa de esplendor: polo papel estelar que desempeña, polo grupo de persoas que o rodea, pola atracción cultural que exerce cara ao exterior e tamén polo seu labor creativo. En Vigo, escribe tamén a novela coa que gaña o Nadal e que o catapulta como narrador.

FV, vicedecano da prensa española — vivía aínda Diario de Barcelona- convértese nun referente cultural que transcende os límites rexionais por mor da achega dos seus directores. Trátase de Leal Insua, poeta; Manuel Cerezales, crítico Literario e mais Álvaro Cunqueiro, fabulador: a terna que comanda o xornal máis culto da súa centenaria historia, tanto pola súa contribución persoal como polos colaboradores dos que se rodean. Os tres, ademais, xorden tan entremisturados que resultan indisociables. Leal é lugués, como Cunqueiro, e é quen o rescata para a profesión cando estaba sancionado. Cerezales será quen lle devolva o carné de xornalista, imprescindible para actuar como director do xornal. Todos eles conseguen que a contraportada de FV sexa a máis brillante da prensa española, ao coincidiren as sinaturas de Cunqueiro — co seu «envés»— e Torrente Ballester — co «a modo». Completa a páxina un terceiro artigo de autores como Carmen Laforet, Delibes, Castroviejo, Fernández del Riego, Risco, Fole.... toda unha longa lista de apelidos sonoros no eido do pensamento.

Porén, o xornalismo da época e, desde logo, o vigués non era un exemplo de perfección. 
Situémonos. Estamos en 1950, o ano no cal Cunqueiro inicia as súas colaboracións. O director de FV, desde 1949, vén ser o viveirense Francisco Leal Insua, un poeta iniciado en El Progreso de Lugo. Leal herda un xornal de combate.

A súa mellor contribución vén ser a formación dunha contorna cultural, en especial literario, que, malia ser minoritaria, fai notarse. El mesmo presume do resultado, anos máis tarde, cando explica: «fixen de FV o xornal dos poetas, con Díaz Jácome e Julio Sigüenza e unha ampla dedicación á lírica».

Como poeta que era, Leal Insua ficha a Cunqueiro en 1950. Vai procuralo a Mondoñedo, onde Álvaro moraba triste, desorientado e no esquecemento literario. Desde 1944, non podía escribir nos xornais porque a Delegación Nacional de Prensa lle retirara o carné profesional, inhabilitándoo no Rexistro Oficial de Xornalistas.

Home do Réxime, a proba de sospeitas nestes anos de represión, Leal Insua é o único director que se atreve a rescatar a Cunqueiro e, cun xesto de valentía que o honra, publica o 25 de xullo de 1950 o primeiro artigo daquel nas páxinas de FV. O texto está dedicado ao río Miño e vén ser o preludio da máxica sección «El pasajero en Galicia», coa que Cunqueiro recobra o seu apelido para a literatura. A xeira de Leal, que eleva o ton culto do xornal, é certamente pre-xornalística, se entendemos por xornalismo aquilo que se exerce na actualidade.

A excelencia recluíase nas columnas de «Opinión». Nomes patriarcais como Otero Pedrayo, Filgueira Valverde, Iglesia Alvariño, Risco... comezan a entremisturarse con autores acabados de chegar como Celso Emilio Ferreiro, José Ruibal —o dramaturgo que se exilia aos EUA — ou Lueiro Rey, que se destaparían no futuro como socialistas ou comunistas. Así, desde unha posición conservadora, FV adscríbese ao galeguismo cultural. Mais o progresismo na opinión non se homologa ao xornalismo en democracia.

Nos anos 60, soan tambores de cambio en FV: unha nova xeración de directivos da familia Lema, propietaria do xornal, chega á primeira liña.

Leal Insua é cesado en xullo de 1961 e trasládase a Madrid. Vén substituílo Manuel Cerezales. Curtido na profesión, Cerezales desembarca en Vigo para modernizar o xornal.

Conta el mesmo - na derradeira entrevista que concedeu, xa nonaxenario (2003), que «eu modernicei FV, que era un xornal do século xIX cando me fixen cargo del. Reducín o formato, modifiquei o deseño». 
No seu tempo implantaron as edicións: Norte — para esa zona xeográfica, con Lugo e A Coruña como eixes- e Sur, o tradicional territorio de FV. Outro dos seus grandes logros foi a incorporación de Torrente Ballester, cuxa fichaxe refire así: «Torrente chegou a Pontevedra coa súa segunda muller e os seus segundos sete fillos. Foi verme a Vigo e pediume para escribir en FV, para poder pagar o aluguer. Precisaba de 18.000 ptas ao mes».

Cerezales abandona FV o 10 de novembro de 1964, data na que toma o relevo Álvaro Cunqueiro, quen, desde marzo de 1965, será xa director oficial.

Cunqueiro pertencía ao equipo de FV desde xuño de 1961. Instalado na redacción, escribe a diario o «envés», encargándose da páxina dominical de «Letras». Estrea tamén o que pode considerarse un xénero literario, os pés de fotos, comentarios de fotografías de actualidade en ton culto e poético. E divírtese cos «prognósticos»: vaticinios sobre os partidos da liga de fútbol.

Díaz Jácome afirma que Cunqueiro lle deu a FV un ton culto coa súa prestixiosa sinatura. O propio Cunqueiro sinala que, no futuro, os estudosos deberán acudir ás páxinas do xornal para coñecer a literatura galega dese período.

Todo iso non significa que o xornalismo informativo, ou de combate, ás veces ao seu pesar, lle resultase alleo. Entre 1966-69, Cunqueiro liberou unha feroz batalla co alcalde da cidade, Rafael Portanet, a propósito do primeiro Plan de Ordenación Urbana de Vigo e aínda outras cuestións nas cales ambos os dous contendentes learon sen contemplacións.

Mellor director do que algunha crítica profesional lle atribúe —e contra a lenda que lle apón certa bohemia laboral—, Cunqueiro era disciplinado, cumpridor estrito e un gran traballador. Durante o seu mandato, o xornal amplía paxinación e aumenta as seccións máis demandadas — como Comarcas—, o que demostra que non carecía de visión comercial.

O debate de se Cunqueiro é, ou non, xornalista está, pois, fóra de lugar, malia as ambigüidades que el mesmo espallou. Foi un bo xornalista. Cando fixo balance da súa traxectoria na dirección, non foi modesto: mellorara o xornal e elevara a súa tiraxe.

É parte capital da cidade de Cunqueiro o gonzo sobre o que xira. Amplifica as anécdotas, os debates, as conferencias, os encontros intelectuais, os lugares frecuentados e os éxitos literarios. É o tempo de esplendor de Cunqueiro. Sen el non existiría. 
